\title{
Diplomatic advantages and threats in global health program selection, design, delivery and implementation: development and application of the Kevany Riposte
}

Sebastian Kevany

\begin{abstract}
Background: Global health programs, as supported by organizations such as the Global Fund to Fight AIDS, Tuberculosis and Malaria and the President's Emergency Plan for AIDS Relief (PEPFAR), stand to make significant contributions to international medical outcomes. Traditional systems of monitoring and evaluation, however, fail to capture downstream, indirect, or collateral advantages (and threats) of intervention selection, design, and implementation from broader donor perspectives, including those of the diplomatic and foreign policy communities, which these programs also generate. This paper describes the development a new métier under which assessment systems designed to consider the diplomatic value of global health initiatives are described and applied based on previously-identified "Top Ten" criteria.
\end{abstract}

Methods: The "Kevany Riposte" and the "K-Score" were conceptualized based on a retrospective and collective assessment of the author's participation in the design, implementation and delivery of a range of global health interventions related to the HIV/AIDS epidemic. Responses and associated scores reframe intervention worth or value in terms of global health diplomacy criteria such as "adaptability", "interdependence", "training," and "neutrality". Response options ranged from "highly advantageous" to "significant potential threat".

Results: Global health initiatives under review were found to generate significant advantages from the diplomatic perspective. These included (1) intervention visibility and associations with donor altruism and prestige, (2) development of international non-health collaborations and partnerships, (3) adaptability and responsiveness of service delivery to local needs, and (4) advancement of broader strategic goals of the international community. Corresponding threats included

(1) an absence of formal training of project staff on broader political and international relations roles and responsibilities,

(2) challenges to recipient cultural and religious practices, (3) intervention-related environmental concerns, and (4) a lack of prima facie consideration of intervention diplomatic and foreign policy consequences.

Conclusions: Global health interventions stand to generate significant diplomatic advantages for donor and recipient countries and organizations when appropriately selected, designed, targeted, and delivered. Conversely, in the absence of the application of standards such as those developed under the Kevany Riposte, threats to diplomacy and international relations may occur. With the application of related systems to other global health programmes and settings, comparative results on the relative worth of alternate approaches from the diplomatic perspective may be generated to better inform political, strategic, and global health policy and programmatic decisions.

Keywords: Global health diplomacy, foreign policy, PEPFAR, HIV/AIDS, the Global Fund to Fight AIDS, Tuberculosis and Malaria, 'smart power'

Correspondence: sebastian.kevany@ucsf.edu

University of California, San Francisco, 550 16th Street, 3rd Floor, San Francisco,

California 94158, USA

\section{Ciomed Central}

(c) 2015 Kevany. This is an Open Access article distributed under the terms of the Creative Commons Attribution License (http://creativecommons.org/licenses/by/4.0), which permits unrestricted use, distribution, and reproduction in any medium, provided the original work is properly credited. The Creative Commons Public Domain Dedication waiver (http:// creativecommons.org/publicdomain/zero/1.0/) applies to the data made available in this article, unless otherwise stated. 


\section{Theoretical \& philosophical basis}

\section{Global health, diplomacy, and foreign policy}

Foreign policy trends in both the European Union and the United States are increasingly aligned with "smart power" [1] approaches, in recognition of the "myriad newer uses" of global health and development initiatives [2]. The European Union advocates strategic use of foreign assistance, combined with diplomacy and arbitration, to pursue foreign policy goals under the Common Foreign \& Security Policy $[3,4]$ via a specific focus on global health [5]. Similarly, in the United States, increasing levels of alignment between the State Department, the United States Agency for International Development, the Department of Defense and the Department of Health and Human Services is indicative of their increasingly interchangeable roles [6]. In the United Kingdom, foreign assistance now forms an integral component of foreign affairs [7] under the stated goal of "policy coherence" [8]. Conversely but convergently, both the United Nations and international military forces have displayed an increased propensity to combine conflict resolution and humanitarian activities [9], whilst the World Bank has recommended that international development focus on security issues beyond primary programmatic goals [10]. These trends are of increasing importance to the design, delivery and evaluation of global health intervention programs under initiatives such as the United States' President's Emergency Plan for AIDS Relief (PEPFAR) [11] particularly in the context of the recent creation of the Office of Global Health Diplomacy [12] and related programs supported by the Global Fund to Fight AIDS, Tuberculosis and Malaria ("The Global Fund") [13].

\section{Aligning \& sensitizing global health programs to international affairs}

Unlike the medically-dominated ethos of global health, diplomatic and foreign policy perspectives are both multilevel and multicausal, involving the synthesis of information from a variety of social science knowledge systems [14]. Failure to consider foreign policy and international relations principles and objectives when designing, selecting and implementing global health programs such as PEPFAR and the Global Fund's related HIV/AIDS initiatives may, therefore, create a "tense and confusing duality" [15]. For example, while global health programs that challenge cultural, religious, ideological, social and behavioral norms are often compelling in terms of their capacity to achieve primary health outcomes, they may also create unquantified downstream benefits, or constitute potential liabilities, from the diplomatic and foreign policy perspectives. Although it is critically important for such initiatives to attempt to optimize outcomes such as quality-adjusted life years (QALYs), their design and delivery needs to be carefully evaluated in order to ensure that (1) these goals are not being achieved at the cost of foreign policy, diplomatic, international relations, or broader global strategic objectives, and (2) their potential to achieve such collateral objectives is optimized [16].

\section{Ranking global health programs from the foreign policy and diplomatic perspectives}

The rise of a utilitarian approach to global health evaluation, as represented by tools such as cost-effectiveness analysis, has resulted in the predominant use of narrow, single-metric measures as exclusive barometers of global health program worth or value [17]. No international initiative, however, operates in isolation or without epistemic consequences [18]. In a variation on the McNamara Fallacy [19], such programs produce a range of downstream, collateral or indirect outcomes that are not adequately quantified - and, therefore, considered to be non-existent. In the $21^{\text {st }}$ century, both foreign policymakers and global health professionals require an innovative métier that reflects these broader considerations, both (1) in order to portray global health expenditures as investments rather than costs, and (2) to "speak a language that people with power really understand" [20]; foreign assistance priorities and associated resource allocation decisions should, where possible, include consideration of the universal and fundamental aspirations of global political, security, and strategic affairs [21]. The recent emergence of the smart power paradigm [22] has, at least in part, been a product of this increased integration between foreign policy and global health initiatives [23], elevating global health to the status of a powerful diplomatic and foreign policy tool, rather than merely a humanitarian effort. There has been, to date, a "lack of ability" to demonstrate the effectiveness of foreign assistance programs in this context [24]. This paper outlines the development and application of just such a "diplomatic assessment" approach for global health programmes, adopting a term from the art of fencing, and eponymously entitled the Kevany Riposte, due to it's conceptual basis as an innovative and interdisciplinary approach that challenges "siloed" [13] or "stovepiped" [25] perspectives. These efforts are based on the author's prior identification of "Top Ten" lists for diplomatic effectiveness [25], and as applied to a retrospective and collective assessment of PEPFAR and Global Fund-supported HIV/AIDS initiatives in South Africa, Sudan, Kenya, South Sudan, Zimbabwe, Tanzania, Iraq, Afghanistan, Egypt, and elsewhere, in order, for the first time, to assess intervention program threats and advantages from this broader perspective.

\section{Methods}

\section{Defining "HIV/AIDS initiatives"}

Community-based behavioral, educational, and diagnostic initiatives form an innovative and essential part of 
both the Global Fund and PEPFAR's HIV/AIDS response paradigms $[26,27]$. Such programs provide, amongst other features, technical assistance to strengthen prevention programming; community support mechanisms; referral systems; and other behavioral and community-based health promotion and educational initiatives [28]. Within this broader operational context, HIV Counseling \& Testing (HCT) based around "wellness days", "community mobilization", and "post-test support services", amongst other forms of service delivery, are provided in community venues in order to increase, for example, numbers of persons tested for HIV/AIDS provided with personalized support and guidance regarding behavioral risk-reduction, as well as raising community awareness and engagement. In the health systems strengthening context, related interventions also contribute to capacity building (e.g. the provision of district-level trainers to implement "Prevention with Positives" programs) [29]. For the purposes of this paper, "HIV/AIDS interventions", "HIV/AIDS programmes", and "HIV/AIDS initiatives" therefore refer to such community-based, multi-level HIV/AIDS responses, including combined diagnostic, prevention, behavioural, and health system strengthening programs under the auspices of Project Accept [30], the Global Fund, and PEPFAR South Africa [31], whilst excluding therapeutic programs such as antiretroviral treatment and surgical interventions such as voluntary adult male circumcision.

\section{Kevany Riposte and K-Score development}

Systems by which to quantify the latent and potential global health diplomacy and foreign policy value of global health programmes were developed based on previouslyidentified criteria for "global health diplomacy" and "global health and foreign policy" appropriateness and effectiveness in global health program design, delivery and evaluation [32]. Originally presented in the form of two "Top Ten" tables - representative of those features or characteristics of global health programs identified as effective in the foreign policy or diplomatic contexts, respectively, in the related literature - classifications were adapted to Excel-based questionnaire and scoring formats (see Additional file 1 Annex 1: Diplomatic Assessment Questionnaire and Scoring Tool). Development of the Kevany Riposte and K-Score also drew on the author's prior contributions to the development and utilization of related designs, in particular the Global Fund's Routine Service Quality Assessment (RSQA) and On-Site Data Verification (OSDV) tools [33]. The results presented in this paper relate specifically to "diplomatic", rather than "foreign policy", considerations.

\section{Implementation \& utilization}

Diplomatic assessments of HIV/AIDS initiatives were based on the retrospective and collective assessment of the author's field deployments for diplomatic monitoring \& evaluation, cost-effectiveness, and quality assurance purposes on behalf of the Global Fund, the United Nations Development Program, PEPFAR implementing organizations (e.g. the International Training and Education Center for Health), the University of California, San Francisco, and the Project Accept community-based voluntary counseling and testing intervention (as implemented under the United States' National Institutes for Mental Health) between 2007 and 2014. Related on-site engagements included field missions to service delivery points (e.g. mobile HIV/AIDS counseling and testing centers in the Northwest Province of South Africa for PEPFAR and in Sudan and South Sudan for the Global Fund) and engagements and liaisons with key governmental and non-governmental organizations and individuals (e.g. the South African, Sudanese and South Sudanese Ministries of Health on behalf of the Global Fund). Field-level and on-site observations conducted to inform assessment responses were undertaken, where possible, with the assistance of an interview guide (see Additional file 2 Annex 2: Interview and Assessment Guide for Diplomatic and Foreign Policy Assessments) and were complemented, where necessary, by follow-up questions via e-mail exchanges and teleconferences with key managerial and field staff. Further on-site and desk research (e.g. review of intervention protocols and standard operating procedures) was also conducted to complete remaining questionnaire responses, as necessary.

\section{Defining assessment classifications \& sub-classifications}

The primary classifications employed in the Kevany Riposte and K-Score were based directly on previouslyidentified "Top Ten" criteria keywords (e.g. "communications"; "adaptability"), as described above. Related sub-classifications were based on interpretations and descriptions of each primary classification in the literature (e.g. the "adaptability" classification was associated with themes of "responsiveness to health needs", "responsiveness to non-health needs", "recipient-led program design", and "recipient-led resource allocation"). For purposes of both detail and consistency, four such sub-classifications were developed for each classification, resulting in 40 assessment questions. In turn, these sub-classifications were expanded and articulated in the form of specific thematic questions to be addressed to relevant project staff, including program managers, field officers, and other project personnel, designed to be relevant to project activities at the individual, intervention and policy levels (see below).

\section{Policy, intervention and individual level assessment dimensions}

As a result of the broad range of issues related to the diplomatically-effective delivery of global health programs, 
the above assessment procedures included implicit consideration of three main evaluation dimensions: (1) policy level (e.g. whether donor organization guidelines addressed relevant practices \& procedures), (2) intervention level (e.g. whether intervention protocol and standard operating procedures were appropriately designed from the diplomatic perspective), and (3) individual level performance and responsibilities (e.g. sensitization of national and international project staff to consideration of broader local, national, and international strategic environments). Sub-classification questions were designed to be informed by, and completed based on consideration of, these three constructs.

\section{Responses, scoring and comments}

Response options to sub-classification questions were divided into six categories: "highly advantageous", "moderately advantageous", "neutral, not relevant, or not considered", "not applicable", "potential moderate threat", and "potential significant threat", in accordance with level of alignment with associated diplomatic goals and principles (Table 1). These response categories were associated with scores of $+2,+1$, zero (for both "neutral, not relevant, or not considered" and "not applicable"), -1 , and -2, respectively. Sub-classification scores were then aggregated and averaged in order to provide an overall classification score. No weighting was attached to different classifications or sub-classifications, based on the assumption that all classifications were of equal value or importance from the diplomatic perspective. Scope for additional comments, narrative descriptions, and categorization justification was also included at the assessment and evaluation stage in order to provide further explanation, as necessary, for scoring decisions. Finally, all classification scores were aggregated and averaged in order to determine an overall intervention-specific diplomatic assessment rating, representative of the collective programs under review, in the diplomatic context (the "K-Score").

\section{Program performance from the diplomatic perspective}

\section{Overall diplomatic assessment results}

Diplomatic assessment ratings at the classification and sub-classification levels are presented in Table 2 and
Additional file 1 Annex 1. The HIV/AIDS initiatives under review were collectively found to be "moderately advantageous" from the diplomatic perspective, attaining an overall average score of +1 across diplomatic assessment classifications. This included three "highly advantageous", three "moderately advantageous", one "neutral", and three "potential moderate threat" classification scores (Fig. 1).

\section{"Highly advantageous" classifications}

HIV/AIDS initiatives were considered to be "highly advantageous" under the diplomatic assessment classifications of "visibility", "adaptability", and "partnerships". These results are in keeping with prior findings related to both the structure and "unintended consequences" of HIV/AIDS intervention programs [18]. For example, the extensive intervention adaptability of related HIV/AIDS interventions has been documented elsewhere [34], including the importance of intervention visibility and communications through revisions to key practices (e.g. evolving intervention "branding" and terminology to fit with local cultures and social norms) and community mobilization activities. Similarly, the generation of international partnerships through collaborations based on international HIV/ AIDS initiatives is in keeping with prior findings related to the documented success of academic and intergovernmental collaborations under both the Global Fund and PEPFAR [35].

\section{"Moderately advantageous" classifications}

HIV/AIDS initiatives under review were found to be "moderately advantageous", from the diplomatic perspective, in terms of "sustainability", "accountability", and "economic, political, environmental and social effects". These findings are also supported by reference to related studies. For example, positive assessments for sustainability were driven by intervention strengths in the context of "country ownership" [36] and transferability to local actors, while diplomatic advantages in the "accountability" context are aligned with previously-documented strengths of PEPFAR and the Global Fund in monitoring and evaluation and other quality assurance and control systems [37]. Similarly, positive economic, political, and social outcomes were driven by the

Table 1 Scoring and Results Classifications for "Top Ten" Criteria

\begin{tabular}{|c|c|c|}
\hline Classification & Interpretation & Score \\
\hline Highly advantageous & Intervention program displays clear and significant value from the diplomatic or foreign policy perspective. & +2 \\
\hline Moderately advantageous & Intervention program displays some strengths in advancing diplomatic or foreign policy goals. & +1 \\
\hline $\begin{array}{l}\text { Acceptable, neutral, or not } \\
\text { relevant }\end{array}$ & Intervention attains diplomatic or foreign policy minimum standards. & 0 \\
\hline Not applicable & Intervention program does not operate in the context of this classification (or sub-classification). & 0 \\
\hline Potential moderate threat & Intervention program may constitute a threat to diplomatic or foreign policy goals. & -1 \\
\hline Potential significant treat & Intervention program constitutes a clear and significant threat from the diplomatic or foreign policy perspective. & -2 \\
\hline
\end{tabular}


Table 2 Diplomatic Assessment Results

\begin{tabular}{|c|c|c|c|c|c|c|}
\hline Classification & Sub-classification 1 & Sub-classification 2 & Sub-classification 3 & Sub-classification 4 & Score & Rating \\
\hline Neutrality & Cultural & Social & Religious & Other & & \\
\hline Neutrality Score & -1 & -1 & -2 & 2 & -1 & $\begin{array}{l}\text { POTENTIAL } \\
\text { MODERATE THREAT }\end{array}$ \\
\hline Visibility & Appropriate Branding & Safety \& Security & National Linkages & $\begin{array}{l}\text { Visibility through } \\
\text { Communications }\end{array}$ & & \\
\hline Visibility Score & 2 & 1 & 1 & 2 & 2 & $\begin{array}{l}\text { HIGHLY } \\
\text { ADVANTAGEOUS }\end{array}$ \\
\hline Sustainability & Sustainability & Transferability & Intervention Type & $\begin{array}{l}\text { Forward-Looking } \\
\text { Commitments }\end{array}$ & & \\
\hline Sustainability Score & -2 & 1 & 2 & 2 & 1 & $\begin{array}{l}\text { MODERATELY } \\
\text { ADVANTAGEOUS }\end{array}$ \\
\hline Effectiveness & Effectiveness & $\begin{array}{l}\text { Constrained } \\
\text { Budgets }\end{array}$ & Cost-Effectiveness & Academic Evidence & & \\
\hline Effectiveness Score & 2 & -1 & -2 & 2 & 0 & NEUTRAL \\
\hline Adaptability & $\begin{array}{l}\text { Responsiveness to } \\
\text { Health Needs }\end{array}$ & $\begin{array}{l}\text { Responsiveness to } \\
\text { Non-Health Needs }\end{array}$ & $\begin{array}{l}\text { Recipient-Led } \\
\text { Program Design }\end{array}$ & $\begin{array}{l}\text { Recipient-Led Resource } \\
\text { Allocation }\end{array}$ & & \\
\hline Adaptability Score & 1 & 2 & 2 & 2 & 2 & $\begin{array}{l}\text { HIGHLY } \\
\text { ADVANTAGEOUS }\end{array}$ \\
\hline Accountability & $\begin{array}{l}\text { Contributions to } \\
\text { M\&E Systems }\end{array}$ & $\begin{array}{l}\text { Production of } \\
\text { Verifiable Results }\end{array}$ & $\begin{array}{l}\text { Presentation of Health } \\
\text { \& Non-Health } \\
\text { Achievements }\end{array}$ & $\begin{array}{l}\text { Combating Corruption and } \\
\text { Increasing Transparency }\end{array}$ & & \\
\hline Accountability Score & 2 & 2 & 1 & -1 & 1 & $\begin{array}{l}\text { MODERATELY } \\
\text { ADVANTAGEOUS }\end{array}$ \\
\hline Partnerships & $\begin{array}{l}\text { Reference to Standards of } \\
\text { International Interaction }\end{array}$ & $\begin{array}{l}\text { Building } \\
\text { International } \\
\text { Alliances }\end{array}$ & $\begin{array}{l}\text { Interaction } \\
\text { Coordinating } \\
\text { Initiatives }\end{array}$ & Sub-National Partnerships & & \\
\hline Partnerships Score & 0 & 2 & 2 & 2 & 2 & $\begin{array}{l}\text { HIGHLY } \\
\text { ADVANTAGEOUS }\end{array}$ \\
\hline $\begin{array}{l}\text { Economic, Political, } \\
\text { Environmental and } \\
\text { Social (EPES) Effects }\end{array}$ & Economic Growth & Political Stability & Social Evolution & Environmental Impact & & \\
\hline EPES Effects Score & 2 & 1 & 2 & -2 & 1 & $\begin{array}{l}\text { MODERATELY } \\
\text { ADVANTAGEOUS }\end{array}$ \\
\hline Interdependence & $\begin{array}{l}\text { Organizational } \\
\text { Relationships }\end{array}$ & Staff Safety & Mission Statements & $\begin{array}{l}\text { Joint Agenda } \\
\text { Accomplishment }\end{array}$ & & \\
\hline $\begin{array}{l}\text { Interdependence } \\
\text { Score }\end{array}$ & -1 & 0 & -1 & -1 & -1 & $\begin{array}{l}\text { POTENTIAL } \\
\text { MODERATE THREAT }\end{array}$ \\
\hline Training & Staff Selection & Staff Recognition & $\begin{array}{l}\text { Education on } \\
\text { Strategic Themes }\end{array}$ & $\begin{array}{l}\text { Diplomatic Risks } \\
\text { and Benefits }\end{array}$ & & \\
\hline Training Score & -2 & 1 & -1 & -1 & -1 & $\begin{array}{l}\text { POTENTIAL } \\
\text { MODERATE THREAT }\end{array}$ \\
\hline $\begin{array}{l}\text { Overall K-Score \& } \\
\text { Assessment }\end{array}$ & & & & & 1 & $\begin{array}{l}\text { MODERATELY } \\
\text { ADVANTAGEOUS }\end{array}$ \\
\hline
\end{tabular}

widespread provision of social and economic support services (such as "Back to Work" or income-generating horticultural schemes), which were frequently attached to those primary service delivery components under review [30].

\section{"Neutral" classifications}

HIV/AIDS interventions were classified as "neutral" from the diplomatic perspective in the context of "effectiveness". The limited consideration of budgetary constraints after the intervention or programmatic support period, combined with the high demand for affordable and costeffective health care delivery and financing strategies in recipient countries, are current causes of concern throughout both the global health and international development contexts [38], most particularly in the current global recession era. In this context, the increased use of both health and non-health effectiveness and cost-effectiveness information as a key component of intervention design 


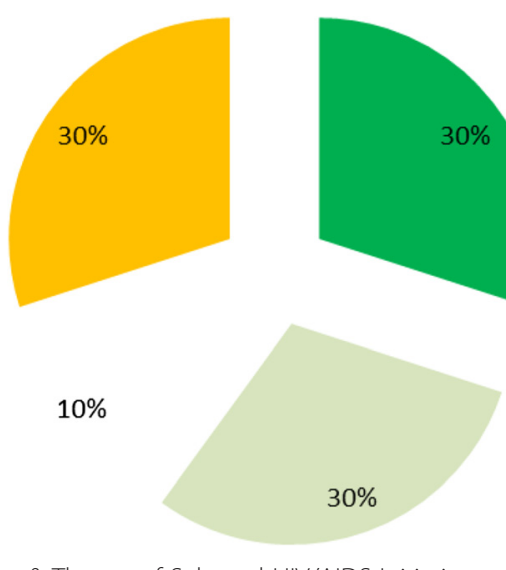

- HIGHLY ADVANTAGEOUS

MODERATELY ADVANTAGEOUS

NEUTRAL

- POTENTIAL MODERATE THREAT

Fig. 1 Diplomatic Advantages \& Threats of Selected HIV/AIDS Initiatives

and delivery on a prima facie rather than a post-hoc basis may significantly strengthen intervention design and delivery [39] in this regard.

\section{"Potential moderate threat" classifications}

Potential moderate threats to diplomatic considerations, interests and outcomes at both recipient and donor levels related to "neutrality", "interdependence", and "training". These findings are, once again, in keeping with a range of contemporary recommendations on the design and delivery of global health intervention programs. For example, in the context of neutrality, the imposition of international cultural, social and religious standards and norms on recipient societies, often without appropriate levels of consultation at the local and community levels, may represent a threat both to successful program implementation and to international relations [34]. Conversely, a lack of awareness of the strategic implications of global health's resource allocation decisions may mean that foreign assistance can unintentionally support extremist organizations [40]. Similarly, in the context of "interdependence", a lack of organizational and operational coordination and alignment between health and non-health initiatives related to broader strategic and international affairs considerations has been identified as a possible source of conflict between health and diplomatic goals [41]. Finally, in the context of "training", limited levels of broader political education and awareness in global health practitioners operating in international environments has been identified as a key gap at the individual capacity level $[42,43]$.

Potential significant threats at the sub-classification level Although no classifications were rated as a "potential significant threat" from the diplomatic perspective, specific sub-classifications recording this result are highlighted here. These include programmatic threats to religious neutrality (under the "neutrality" classification), limited assurances and planning regarding funding sustainability (under the "sustainability" classification), limited or no prima facie use of health and non-health cost-effectiveness findings (under the "effectiveness" classification, and as described above), limited or no consideration of environmental impact (under the "economic, political, environmental and social effects" classification), and inadequate provision of broader diplomatic training, awareness, and formalization of related roles and responsibilities (under the "training" classification). Strategies to address these potentially significant diplomatic threats have been presented, in recent years, via innovative recommendations on the $21^{\text {st }}$ century design and delivery of global health service delivery [13].

\section{Interpretation \& conclusions Key findings}

For the first time, a global health intervention has been assessed through the lens, and from the perspective, of diplomatic appropriateness, sensitivity and effectiveness. HIV/AIDS initiatives were found to score positively in terms of diplomatic effectiveness, whilst also evincing both (1) potential areas of improvement and (2) a limited number of potential diplomatic threats. These findings may represent significant considerations for policymakers both within and beyond global health, who are now equipped to determine the value, worth or risk of global health investments beyond the narrow metrics employed by traditional monitoring and evaluation or costeffectiveness analyses associated with a narrow (and often exclusively medical) selection of outcomes, outputs and impact assessments [44]. These results should, nonetheless, still be considered in conjunction with traditional measures of program effectiveness or efficiency in order to determine associated resource allocation and implementation decisions: low levels of intervention cost-effectiveness, for example, may be 
offset by significant intervention returns or value at the diplomatic level [35].

\section{Enlightened strategic \& resource allocation decisions: beyond cost-effectiveness}

The results presented here are designed for use and reference at both the global health policy level and across the broader milieu of bilateral and multilateral foreign policymaking and practice. For example, within global health and development, these results may help to inform "enlightened" resource allocation decisions beyond the "potentially flawed" [35] reliance on costeffectiveness analyses as the exclusive determinant of global health program worth or value. Perhaps even more importantly, the interpretation and use of these results at the diplomatic and foreign policy level presents a range of opportunities for policymakers to leverage, design, and refine global health and other development initiatives for the purposes of foreign policy and diplomacy [45].

\section{"Smart power" and "smart global health"}

At its most optimal, the Kevany Riposte and the K-Score may help both health and non-health, bilateral and multilateral organizations to manipulate aid in order to substitute for, offset, complement, or support the use of hard power in favour of smart power options, via the creation of a new "stage" in the escalation of international engagements, in keeping with $21^{\text {st }}$ Century standards of acceptability for, and effectiveness of, international military interventions $[46,47]$. A new step in the "escalation hierarchy" amongst traditional and accepted stratifications such as neutrality, diplomacy, soft power and hard power [48] would be epitomized by such smart global health initiatives [45]. This may, in turn, bring about (1) a transfer or collaboration of resources from hard to smart international initiatives operating under "military umbrellas" [46] and, where feasible and appropriate, (2) the increased or enhanced use by military forces and related organizations of smart global health systems to pursue foreign policy and strategic prerogatives [49].

\section{Utilization in the international intelligence context}

The employment of global health programs for strategic political ends in an unstructured manner has, in the past, put global health workers at a security risk by association, regardless of whether or not individual- or organizational-level activities are in fact related to such ostensibly extraneous objectives [50]. At the same time, Western powers are increasingly open to the use of innovative, collaborative and interdisciplinary efforts to resolve contemporary international affairs and security challenges [51], against which conventional response systems have faced significant challenges. In this highly nuanced, complex, and occasionally clandestine context, non-health dividends may be attained if global health programs are selected, designed and delivered in a manner that bears in mind potential international conflict resolution, cooperation, and security goals as well as primary health and development outcomes [52]; past research has suggested that locating highly-diplomatic global health projects in extremist regions, as informed by the "geo-strategic considerations" classification, provides meaningful alternatives to political or other forms of extremism [53]. In this context, the Kevany Riposte and the K-Score may offer standards by which international agencies such as the United Kingdom's Security Service,(MI5), the European Union's Intelligence Analysis Centre [54], and the United States' Central Intelligence Agency (CIA) liaise with both donor, supranational, and recipient departments of international development and health in a fashion that both (1) reduces threats to aid workers and (2) integrates multifarious dimensions to global health programs which are, in turn, (3) conducted in a style acceptable and transparent to recipient country governments. Such innovative collaborations, instead of acquiescing to demands that global health funding be transferred to defense [55], stand to achieve both altruistic, intelligence, and security goals simultaneously. Perhaps most importantly, employment of assessment systems under the Kevany Riposte in this context will also help to ensure that global health programs do not inadvertently harm international security by providing aid, health, or other financial support to extremist organizations [56]. Notwithstanding these other potential gains, traditional (and possibly flawed) approaches to intelligence gathering through international development initiatives [57] stand to be both improved and made more effective by the application of relevant criteria, models, procedures and standards to both organizational and individual-level activities and liaisons in this context.

\section{Limitations}

The absence of comparator results from other global health intervention programs is a key limitation of this work. The generation of relevant comparable "K-Scores" in different settings (e.g. the diplomatic effectiveness of tuberculosis treatment programs in Iraq or malaria prevention initiatives in Afghanistan, as described elsewhere by the author) $[17,52]$ may, as with the results of costeffectiveness analyses, generate opportunities for intervention ranking or league tables [58] from the diplomatic or foreign policy perspective. For example, comparisons with HIV/AIDS interventions excluded from this review (e.g. antiretroviral treatment or male circumcision) might provide useful information to 
policymakers regarding related resources allocation decisions. This review should, therefore, be characterized and interpreted as a pilot initiative, based on which, in future, Kevany Riposte systems, scope, and results may be further refined and applied by larger teams. In addition, future efforts might also (1) consider dividing the system's structure and results across the three major evaluation dimensions outlined above (i.e. individual, policy and intervention levels) in a more explicit fashion, (2) correlate health and diplomatic outcomes (see below), and (3) attempt to further describe the political and operational mechanisms by which the results of diplomatic and foreign policy evaluations may be translated from findings such as those presented here into policy, and thence into practice [59-61] (see below).

\section{Plotting health effectiveness against intervention effectiveness}

A related area of potential interest and inquiry to organizations such as the United States' Centers for Disease Control and Prevention (CDC) is consideration of the effects of diplomatically "highly advantageous" global health interventions on health outcomes. Do "more diplomatic" global health interventions relate to improved health outcomes - or vice versa - or both? Such findings, though beyond the scope of this paper, might be determined through cross-referencing intervention medical efficacy and effectiveness against diplomatic assessment values. Though direction of causality may be challenging to prove, the establishment of such relationships may help to further explain the manifold connections between diplomatically and medically successful global health interventions [62].

\section{Recommendations}

Global health interventions and related Global Fund and PEPFAR-supported programs have the potential to be of significant importance in alleviating developing countries from the worst effects of communicable and noncommunicable disease and ill-health. More broadly, such interventions may also have the potential to advance diplomatic considerations related to the interests of both donor and recipient countries, as well as national and international, health and non-health, goals and initiatives, such as strategic and security concerns. In order to optimize the potential future impact of these latter dimensions, and based on the results presented here, related recommendations include (1) consideration of the redesign of HIV/AIDS initiatives in the context of training, organizational interdependence, and neutrality, whilst also addressing the specific "potential significant threats" at the sub-classification level described above; (2) the further development of intervention sustainability, accountability, and latent political, economic, social and environmental potential; (3) the development and prima facie integration of intervention health and nonhealth effectiveness findings into intervention program design and delivery; (4) building on the successes and diplomatic advantages associated with intervention visibility, adaptability, and partnership development; and (5) leveraging these latent diplomatic assets, at the individual, intervention and policy levels, in order to address broader national and international strategic concerns.

\section{Next steps: utilization of results and "evidence into policy \& practice"}

The identification of five main opportunities and mechanisms for utilization of the results of the Kevany Riposte and K-Score have previously been identified by the author as (1) training, (2) evaluation, (3) resource allocation, (4) funding, and (5) military and international security considerations [25]. A range of realpolitik scenarios for such applications are conceivable. In one possible example, widespread diplomatic reviews conducted under the auspices of organizations such as the Office of Global Health Diplomacy, the United Kingdom's Royal Institute for International Affairs, or the European Union's External Action Service, might provide a detailed picture of the comparative worth of global health interventions, from the diplomatic and foreign policy perspectives, across a range of key settings, population groups, and regions around the world. These results might then be overlaid, with the assistance of donor and recipient country foreign policymakers or professional diplomats, with global diplomatic, political, foreign policy or strategic needs and threats in order to determine both (1) overall and targeted global health investments, (2) geo-strategic and demographic focus, and (3) intervention program selection, whilst (4) better aligning interventions with broader strategic considerations and the work of non-health international initiatives and organizations. In this way, the smart use of global health initiatives may provide a meaningful and effective alternative or complement to other forms of international intervention on the world stage, advancing both health and non-health goals [63].

\section{Additional files}

Additional file 1: Annex 1 Diplomatic Assessment Questionnaire and Scoring Tool.

Additional file 2: Annex 2 Interview and assessment guide for diplomatic and foreign policy assessments.

Competing interests

The author declares that he has no competing interests.

\section{Acknowledgements}

Professor George Rutherford (University of California, San Francisco), Professor Ruairi Brugha (Royal College of Surgeons in Ireland), Professor David Heymann (Royal Institute for International Affairs), Professor Thomas 
Novotny (University of California San Diego), Dr. Carlos Bruen (Royal College of Surgeons in Ireland), Professor Charles Normand (Trinity College Dublin), Dr. Starley Shade (University of California, San Francisco), Mr. Bertie Anter (SDL-BOL Advisory International), Ms. Jessica Grignon (I-TECH South Africa), Mr. Kevin Boden (Lincap International). Dr. James G. Kahn (University of California, San Francisco), Mr. Len Brennan (St. Andrew's College, Dublin).

\section{Received: 21 January 2015 Accepted: 6 May 2015} Published online: 27 May 2015

\section{References}

1. Ferrero-Waldener B (2007). The European Union and the World: A Hard Look at Soft Power. New York: Columbia University. September 24 ${ }^{\text {th }}, 2007$.

2. Lancaster C. Foreign Aid: Diplomacy, Development. Domestic Politics: University of Chicago Press; 2007.

3. Europa (2010). Foreign and Security Policy: Speaking with One Voice. Accessed through: www.europa.eu/pol/cfsp/index_en.htm

4. Kagan R. Power and Weakness. Policy Review. 2002;113:208-21. Retrieved from https://www.mtholyoke.edu/acad/intrel/bush/kagan.htm.

5. European Commission (2010). The EU Role in Global Health. European Commission consultation document. Brussels: March 2010 Accessible through: https://ec.europa.eu/europeaid/eu-role-global-health_en

6. Department of State (2008). Joint Department of State, USAID Enterprise Architecture Transition Strategy for FY2009. Accessed through: http:// www.state.gov/m/irm/rls/110469.htm

7. Tran M (2012). The Politics of UK Aid Explained. The Guardian. September $26^{\text {th }}, 2012$. Accessible through: http://www.theguardian.com/globaldevelopment/2012/sep/26/the-politics-uk-aid-explained

8. Kitchen N (2010). The Future of UK Foreign Policy: Executive Summary IDEAS reports - special reports, Kitchen, Nicholas (ed.) SR006. LSE IDEAS, London School of Economics and Political Science, London, UK. Accessed through: http://eprints.Ise.ac.uk/43547/1/The\%20future\%20of\%20UK\%20foreign\%20policy_executive\%20summary (Isero).pdf

9. The Lancet (2015). National Armies for Global Health? The Lancet 384: 1477. Retrieved from: http://www.thelancet.com/journals/lancet/article/PIIS01406736(14)61923-1/fulltext?rss=yes

10. The World Bank (2011). The World Development Report 2011: Conflict, Security, and Development. Accessed through: http://wdr2011.worldbank.org/ fulltext

11. O'Neill J \& Pappas G (2007). Health Diplomacy: Lessons for Global Health from PEPFAR. The International Journal of World Health and Societal Politics. 7: 1. Accessed through: https://ispub.com/IJWH/7/1/3801.

12. United States Department of State (2014). About the Office of Global Health Diplomacy. Accessible through: http://www.state.gov/s/ghd/about/

13. Novotny T, Kevany S. The way forward in global health diplomacy: Definitions, research, and training. In: Novotny T, Kickbusch I, Told M, editors. 21st century health diplomacy. Geneva: World Scientific; 2013. p. $203-25$

14. Hudson V, Vore C (1995). Foreign policy Analysis: Yesterday, Today and Tomorrow. Mershon Int Stud Rev. 39 (2): 209-38. Accessible through: http:// bev.berkeley.edu/fp/readings/ForeignPolicyAnalysisDomesticPolitics.pdf.

15. Center for Strategic and International Studies (2010). Final Report of the CSIS Commission on Smart Global Health Policy. Accessed through: http:// csis.org/event/rollout-final-report-csis-commission-smart-global-health-policy

16. Feldbaum H. Global Health \& Foreign Policy. Epidemiological Review. 2010;32:82-92.

17. Kevany S, Jaf P, Workneh N, Abu Dalo M, Tabena M, Rashid S \& Al Hilfii T (2014). Global health diplomacy in Iraq: international relations outcomes of multilateral tuberculosis programmes. Medicine, Conflict and Survival 30 (2): http://dx.doi.org/10.1080/13623699.2014.890827

18. Lyman N \& Wittels S (2010). No Good Deed goes Unpunished: The Unintended Consequences of Washington's HIV/AIDS programs. Foreign Affairs. July-August 2010. Retrieved from http://www.foreignaffairs.com/ articles/66464/princeton-n-lyman-and-stephen-bwittels/no-good-deed-goesunpunished

19. Basler M. Utility of the McNamara Fallacy. Br Med J. 2009;339:b3141-23.

20. 24. Nye J (2004). The Decline of America's Soft Power. Foreign Affairs: May \& June 2004 Issue. Accessible through: https://www.foreignaffairs.com/articles/ 2004-05-01/decline-americas-soft-power
21. Warmerdam W \& de Haan A (2011). The Roles of Aid in Politics. International Institute for Social Studies. Accessible through: www.iss.nl/ Bibliography_The_Roles_of_Aid_in_Politics_February_

22. Center for Strategic \& International Studies (2007). The CSIS Commission on Smart Power. Accessible through: http://csis.org/files/media/csis/pubs/ 071106_csissmartpowerreport.pdf

23. Feldbaum H, Michaud J. Health Diplomacy and the Enduring Relevance of Foreign Policy Interests. PLoS Med. 2010;7(4), e1000226. doi:10.1371/ journal.pmed.1000226.

24. Bonventre E. Monitoring and Evaluation of Department of Defense Humanitarian Assistance Programs. Military Review. 2008;88(1):66-72.

25. Garrett $L$ (2007). The Challenge of Global Health. Foreign Affairs. January \& February 2007 Issue. Accessible through: https://www.foreignaffairs.com/ articles/2007-01-01/challenge-global-health

26. PEPFAR (2014). PEPFAR Prevention Guidance. Accessible through: http:// WwW.PEPFAR.gov/reports/guidance/171094.htm

27. The Global Fund (2012). The Global Fund Strategy 2012-2016. Accessible through: www.theglobalfund.org/Core_GlobalFundStrategy01_Attachment_en/

28. United States Global health Initiative (2011). Global Health Initiative Strategy 2011-2016. Accessible through: http://www.ghi.gov/whereWeWork/docs/ SouthAfricaStrategy.pdf

29. PEPFAR (2010). Kenya Country Operational Plan 2010. Accessible through: www.PEPFAR.gov/documents/organization/228466.doc

30. Khumalo-Sakutukwa G, Morin S, Fritz K, Charlebois E, Van Rooyen H, Chingono A, et al. The NIMH Project Accept Study Team (2010). Project Accept (HPTN 043): A Community-Based Intervention to Reduce HIV Incidence in Populations at Risk for HIV in Sub-Saharan Africa and Thailand. J Acquir Immune Defic Syndr. 2008;49(4):422-31. http://www.academia.edu/ 8166578/Project_Accept_HPTN_043_A_Community-Based_Intervention_to_Reduce_HIV_Incidence_in_Populations_at_Risk_for_HIV_in_Sub-Sahara.

31. International Teaching and Education Center for Health (2014). South Africa: I-TECH Launches Re Mmogo Pholong [Together In Wellness] Program. Accessible through: http://news.go2itech.org/2012/10/south-africa-wellnessprogram/

32. Kevany S (2014). Global Health Diplomacy, 'Smart Power', and the New World Order. Global Public Health: An International Journal for Research, Policy and Practice. 2014. doi:10.1080/17441692.2014.921219.

33. The Global Fund (2014). Data and Service Quality Assessment. Accessible through: http://www.theglobalfund.org/en/me/documents/dataquality/

34. Kevany S, Khumalo-Sakutukwa G, Murima O, Chingono A, Modiba P, Gray G, et al (2013). Health diplomacy and adapting global health interventions to local needs in sub-Saharan Africa and Thailand: evaluating findings from Project Accept. BMC Public Health. 2012;12(459):1-11. http://www. biomedcentral.com/1471-2458/12/459/abstract.

35. Walensky R, Kurtizkes G (2011). The Impact of The President's Emergency Plan for AIDS Relief (PEPFAR) beyond HIV and Why It Remains Essential. Clin Infect Dis. 50 (2): 272-5. Accessible through: http://cid.oxfordjournals.org/ content/50/2/272.abstract.

36. United States Agency for International Development (2013). Issue Brief Country Ownership. Accessible through: http://www.usaid.gov/sites/default/ files/documents/1864/CountryOwnershiplssueBrief.pdf

37. Kevany S, Hatfield A, Workneh N, Aurang Zeb Durrani B, Bekele Y, Khan U, et al. Diplomatic and operational adaptations to global health programs in post-conflict settings: contributions of monitoring and evaluation systems to 'nation-building' in South Sudan. Med, Confl Surviv July-September; 2012;28(3):247-62. http://www.ncbi.nlm.nih.gov/pubmed/23189590.

38. Yang A, Farmer P. Sustainability: in Global health. Glob Public Health 2010;5(2):129-35. Accessible through: http://www.ncbi.nlm.nih.gov/ pubmed/20213563.

39. United Kingdom Medical Research Council (2007). Developing and evaluating complex interventions: new guidance. Accessible through: http:// www.mrc.ac.uk/documents/pdf/complex-interventions-guidance/

40. Eckenwiler L, Hunt M. Counterterrorism, Ethics, and Global Health. Hastings Cent Rep. 2014;44(3):12-3. Accessible through: http:// www.thehastingscenter.org/Publications/HCR/Detail.aspx?id $=6885$.

41. Royal Institute for International Affairs (2011). Global Health Diplomacy: A Way Forward in International Affairs. Accessible through: https:// www.chathamhouse.org/sites/files/chathamhouse/public/Research/ Global\%20Health/280611summary.pdf

42. Katz R, Kornblet S, Arnold G, Lief E, Fischer J. Defining health diplomacy: Changing demands in the era of globalization. Milbank Q. 2011;89:503-23. 
Retrieved from http://onlinelibrary.wiley.com/doi/10.1111/j.14680009.2011.00637.x/abstract.

43. Kickbusch I, Novotny T, Drager N, Silberschmidt G, Alcazar S. Global health diplomacy: Training across disciplines. Bulletin of the World Health Organization. 2007;85:82-91. Retrieved from http://www.scielosp.org/ scielo.php?pid = S004296862007001200027\&script $=$ sci_arttext\&tlng $=$ es

44. Marseille, E., \& Khan, J. (2002). HIV prevention before HAART in sub-Saharan Africa. The Lancet, 359, 1851-1856. Retrieved from http://www.thelancet.com/journals/lancet/article/PIIS0140-6736(02)08705-6/abstract

45. Center for Strategic and International Studies. (2010). Final report of the CSIS Commission on smart global health policy. Retrieved from http:// csis.org/event/rollout-final-report-csis-commission-smart-global-health-policy

46. Burkle S (2013). Throwing the baby out with the bathwater. Prehosp Disaster Med. (3):1-3. Retrieved from http://journals.cambridge.org/action/ displayAbstract?fromPage $=$ online\&aid $=892159$

47. Burkle S, Garfield R. Civilian mortality after the 2003 invasion of Iraq. The Lancet. 2013;381:879. Retrieved from http://press.thelancet.com/ mortality.pdf.

48. Copeland D, Potter E. Public Diplomacy in Conflict Zones: Military Information Operations Meet Political Counter-Insurgency. The Hague J Diplomacy. 2008;3(3):277-97. Accessible through: http://booksandjournals. brillonline.com/content/journals/10.1163/187119108×367161?crawler=true

49. Center for Strategic \& International Studies (2014). Global Health Engagement: Sharpening a Key Tool for the Department of Defense. Accessible through: http://csis.org/files/publication/ 140930_Daniel_DODGlobalHealth_Web.pdf

50. United States Agency for International Development (2009). Development Assistance and Counter-Extremism. USAID Policy Document. Accessible through: https://dec.usaid.gov/dec/content/GetDoc.axd?

51. Vanderwagen W (2006). Health Diplomacy: Winning Hearts and Minds thorough the use of Health Interventions. Military medicine 171: 3-4. White B (2001). The Globalization of World Politics: An Introduction to International Relations. New York: Oxford University Press

52. Kevany S, Sahak O, Workneh N, Saeedzai A. Global health diplomacy investments in Afghanistan: adaptations and outcomes of Global Fund malaria programs. Med Confl Surviv. 2014;30(1):37-55. http:// www.tandfonline.com/doi/pdf/10.1080/13623699.2014.874187.

53. Novotny T, Adams V. Global health diplomacy —A call for a new field of teaching and research. San Francisco Medicine. 2007;80(3):22-3.

54. Europa (2015). Factsheet on EU Intelligence Analyses Center (INTCEN). Accessible through: http://eu-un.europa.eu/articles/en/article_16050_en.htm

55. Norton-Smith R (2015). MI5, 'Jihadi John', terrorism, UK defense, budgets- all connected. The Guardian. Defense and Security Blog, March 2nd, 2015. Accessible through: http://www.theguardian.com/news/defence-andsecurity-blog/2015/mar/02/mi5-jihadi-john-terrorism-uk-defence-budgets-allconnected

56. Williams J (2015). Countering violent extremism: improving U.S. strategy for the future. Brookings Institution: Middle East Politics \& Policy Department. Accessed through: http://www.brookings.edu/blogs/markaz/posts/2015/02/ 06-countering-violent-extremism

57. Hider J (2014). US sent fake aid workers to spy on Cuba. The Times, US \& Americas. August $5^{\text {th }}, 2014$. Accessible through: http://www.thetimes.co.uk/ tto/news/world/americas/article4166629.ece

58. Using cost-effectiveness league tables to compare interventions to prevent sexual transmission of HIV. Pinkerton S (2001). AIDS 215(7): 917-28. Accessible through: http://www.ncbi.nlm.nih.gov/pubmed/11399964

59. Yamey G. Evidence-Based policymaking in Global health: The Payoffs \& Pitfalls. Evid Based Med. 2011;16:97-9. Accessible through: http://ebm.bmj.com/content/16/4/97.

60. Brown M, Mackey T, Shapiro C, Kolker J, Novotny T (2014). Bridging Public Health and Foreign Affairs: The Tradecraft of Global Health Diplomacy and the Role of Health Attachés. Science \& Diplomacy 3: 3. Accessed through: http://www.sciencediplomacy.org/article/2014/bridging-public-health-andforeign-affairs

61. Kevany, S., Benatar, S., \& Fleischer, T. (2013). Improving resource allocations for health and HIV in South Africa: Bioethical, cost-effectiveness and health diplomacy considerations. Global Public Health, 8, 570-587. Retrieved from http://www.ncbi.nlm.nih.gov/pubmed/23651436
62. Kleinman A (2010). The art of medicine: Four social theories for global health. Vol 375 May 1, 2010. Accessible through: http://www.thelancet.com/ pdfs/journals/lancet/PIIS0140673610606460.pdf

63. Michaud J, Kates J. Global health diplomacy: Advancing foreign policy and global health interests. Global Health: Science \& Practice. 2013;1 (1):24-8. Retrieved from http://www.ghspjournal.org/content/1/1/24.full.

\section{Submit your next manuscript to BioMed Central and take full advantage of:}

- Convenient online submission

- Thorough peer review

- No space constraints or color figure charges

- Immediate publication on acceptance

- Inclusion in PubMed, CAS, Scopus and Google Scholar

- Research which is freely available for redistribution 